\title{
Review of Dizionario biografico delle scienziate italiane (secoli XVIII-XX)
}

\author{
Vol. 1 by Miriam Focaccia (ed.), vol. 2 by Sandra Linguerri (ed.). Preface by Raffaella \\ Simili. Bologna, Pendragon (2012)
}

\author{
Rossana Tazzioli
}

Published online: 3 August 2013

(C) Centro P.RI.ST.EM, Università Commerciale Luigi Bocconi 2013

\begin{abstract}
The two volumes of the Dizionario biografico delle scienziate italiane include the biographies of more than a hundred women scientists and provide an idea of the difficulties that women scientists encountered in different periods of Italian history.
\end{abstract}

Keywords Women scientists · Women mathematicians - History of science $\cdot$ History of mathematics · Gender studies

Some readers will know the Internet site 'Scienza a due voci' (http://scienzaa2voci.unibo.it), which is very useful for retrieving information about women scientists, quite often difficult to obtain by means of the usual instruments. This website, still in progress, was presented in 2008 at the Genova Festival della Scienza, but has behind it a long history. It began in 2000 at the University of Bologna with a series of meetings regarding women in scientific institutions and in universities from the 1700s to the 1900s, and then continued with the publication of various articles and books.

The two volumes of the Dizionario biografico delle scienziate italiane [2] carry on, and in some senses crown, this history. The lives of more than a hundred women are reviewed, and thanks to entries that are always accurate and organised according to biographical profiles, original works and secondary bibliographies, give us an idea of the difficulties that women scientists encountered in different periods of Italian history (Figs. 1, 2).

R. Tazzioli $(\bowtie)$

UFR de Mathématiques, Université de Lille 1,

59655 Villeneuve d'Ascq, (France)

e-mail: rossana.tazzioli@univ-lille1.fr
Publications regarding the role of women scientists in society do not represent an entirely new genre. They began to multiply beginning in the $1980 \mathrm{~s}$, thanks above all the studies of Margaret W. Rossiter, a pioneer in so-called gender studies. Thus in 1986 was published the dictionary entitled Women in Science: Antiquity Through the Nineteenth Century: A Biographical Dictionary with Annotated Bibliography [4], whose second edition, released in 2000, contains no fewer than 2,500 entries. If we recall that the famous Dictionary of Scientific Biography, edited by Gillispie [1] contained entries for twenty-five women scientists, we see that the progress made in gender studies is indeed remarkable!

The two volumes edited by Miriam Focaccia and Sandra Linguerri thus represent a useful working tool for specialised historians, but they also offer more. Reading about the lives and careers of so many women allows 'non-experts' to form an idea of the real impediments that for a long time (and still today) hindered women from entering into Italian science.

In Italy, as in the rest of Europe, starting in the 1700 s women began participating actively in science as interlocutors of the great intellectuals. We need only recall Madame du Châtelet, the muse of Voltaire and translator of Newton's Principia, but there are other examples in Italy, such as Eleonora Barbapiccola, the bella cartesiana (beautiful Cartesian) who translated the Principia Philosophiae by Descartes, and Maria Angela Ardinghelli, translator of the works of the physicist Stephen Hales. Among women mathematicians we recall the Milanese Maria Gaetana Agnesi, who came from a cultured, well-todo background, author of a two-volume work published in 1748 entitled Istituzioni analitiche ad uso della gioventù italiana, which became an important reference for the analysis of the 1700s, and was translated into English and 


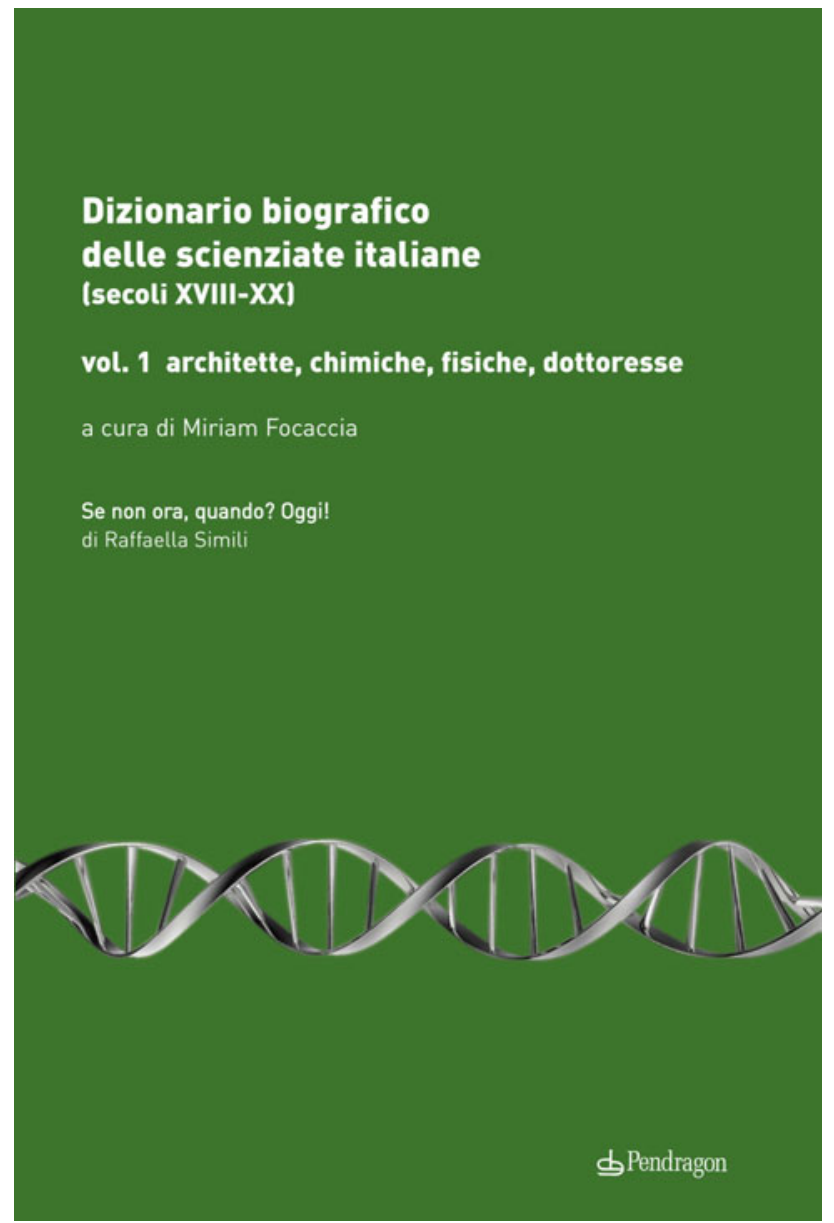

Fig. 1 Dizionario biografico delle scienziate italiane (secoli XVIII$X X)$, vol. 1

French. Among the curves discussed in this work, Agnesi dealt with the famous 'versiera', still today associated with her name (known in English as 'the Witch of Agnesi').

Beginning in 1874, the year in which new regulations were approved permitting women to enrol in university, an increasing number of women were awarded degrees. Thus we find the stories of famous women, such as Maria Montessori, creator of a new 'positive pedagogy'; Anna Kuliscioff, socialist and physician, the 'doctor of the poor'; and the Nobel Laureate Rita Levi Montalcini. However, in these volumes there also figure women who are less well known, such as Emma Modena, a pioneer in the field of hygiene; Gaetanina Calvi, the first Italian civil engineer; and Marianna Spallanzani, who assisted her more famous brother Lazzaro in curating his imposing private zoological collection. For many of these women, their devotion to science was possible only at the expense of many sacrifices and often in the shadow of a male protector, perhaps a brother, husband or father.

Just at the end of the nineteenth century Alfonse Rebière published his book entitled Les femmes dans la science [5],

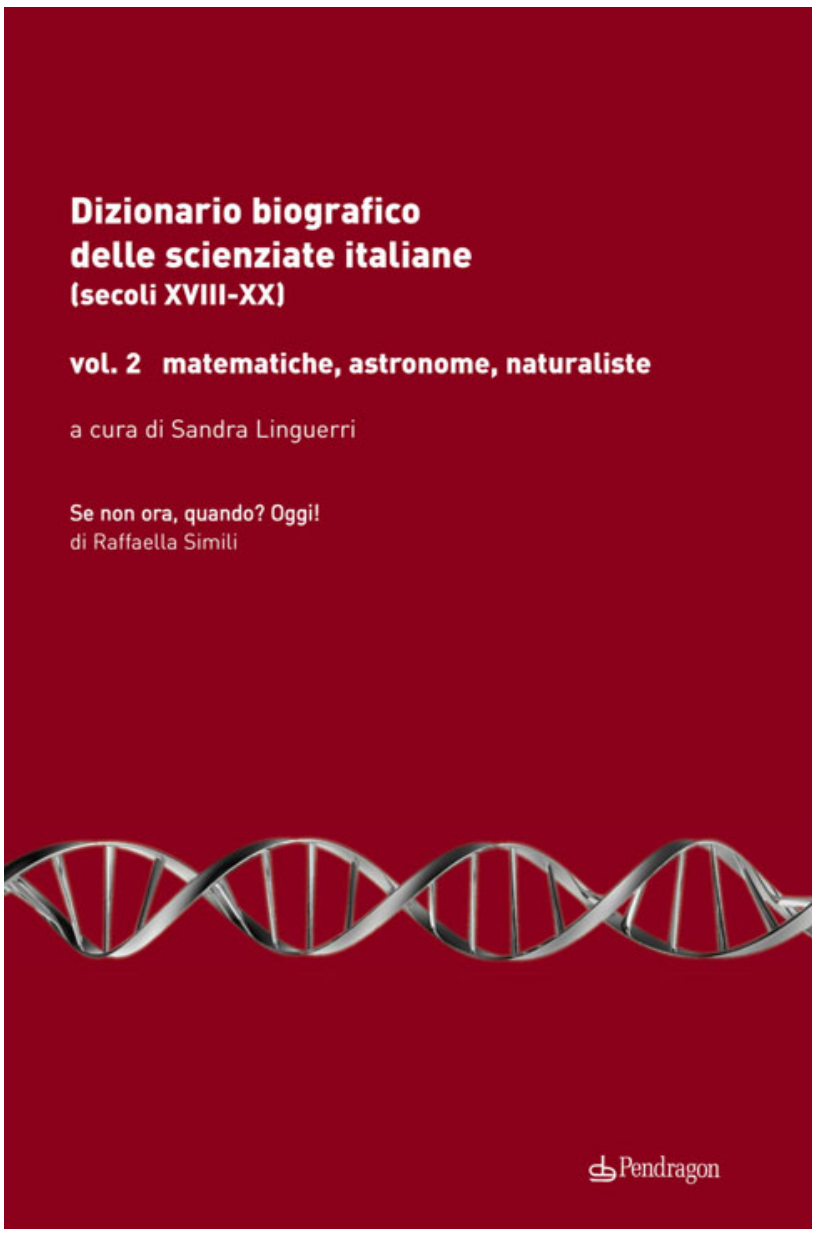

Fig. 2 Dizionario biografico delle scienziate italiane (secoli XVIII$X X)$, vol. 2

which lists 617 women, including 58 Italians. However, a few years later the Italian mathematician Gino Loria displayed an attitude that was much less open-minded. In his lecture of 1901 dedicated to 'mathematical women' [3], Loria testified to the incapacity of women to escape from 'all scholastic subjection' in order to free themselves into the high spheres of knowledge. To support his opinion, Loria referred to studies of physicians and anthropologists of the likes of Cesare Lombroso, Guglielmo Ferrero and Paolo Mantegazza.

The most salient aspects of Loria's point of view were taken up during the Fascist period, when women were viewed as daughters, mothers or brides rather than as intellectuals gifted from birth with the same capacities as their male colleagues. In the school reforms of 1923 Giovanni Gentile, Minister for Public Education, introduced a lyceum for girls that offered no professional diplomas and provided no entrance to universities. In 1927, women were even excluded from teaching literary and philosophical subjects in high schools. 
Fortunately, these prejudices and sexist attitudes were not shared by all, neither during Loria's day nor in the period that followed. To the contrary, there were many scientists who had women as students and who continued to follow them and encourage their research. Noteworthy among the mathematicians are Giuseppe Peano, Tullio Levi-Civita and Vito Volterra, and among the naturalists Giovanni Battista Grassi, Camillo Golgi and Pietro Pavesi. These great figures formed generations of intellectuals, many of whom were women. Elena Freda, Pia Nalli, Pierina Quintili, Maria Pastori, Maria Gramegna and Cornelia Fabri are just a few of the scientists, in some rare cases future university professors and more often assistants and then secondary school teachers, who were students more or less directly of these outstanding mathematicians.

We too, as Raffaella Simili writes in her Preface, hope that the works on the history of women can, on one hand, inspire new historical investigations, and on the other contribute to the solution of urgent social and civil problems regarding justice, equality and liberty for women. As the popular protest phrase used in Italy today says, "If not now, when?" Today!

Translated from the Italian by Kim Williams

\section{References}

1. Dictionary of Scientific Biography. 16 vols. C. G. Gillispie (ed.) Charles Scribners' Sons, New York (1970-1980)
2. Dizionario biografico delle scienziate italiane (secoli XVIII-XX), vol. 1 by Miriam Focaccia (ed.), vol. 2 by Sandra Linguerri (ed.). Preface by Raffaella Simili. Pendragon, Bologna (2012)

3. Loria, G. Donne matematiche. Lecture given at the Reale Accademia Virgiliana di Mantova, 28 December 1901. Published as Le Transfigurazioni di una scienza; donne matematiche, Mantova (1902)

4. Olgivie, M.B.: Women in Science: Antiquity Through the Nineteenth Century: A Biographical Dictionary with Annotated Bibliography. MIT Press, Cambridge (1986)

5. Rebière, A.: Les femmes dans la science. Librairie Nony \& cie, Paris (1897)

\section{Author Biography}

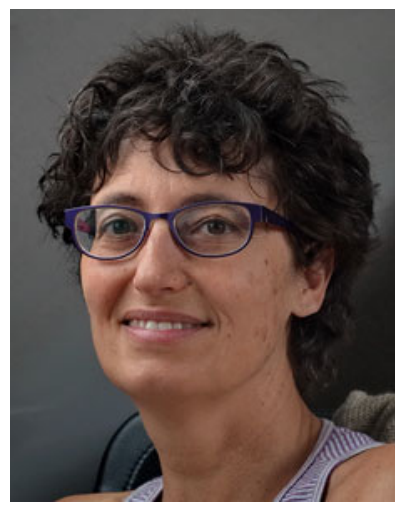

Rossana Tazzioli has taught history of mathematics at the Université Lille 1 since 2008. She has published various articles, essays and books for a general audience on the history of science. She is the author of Riemann. Le géomètre de la nature (Paris, Belin, 2010) and published in collaboration with Laurent Mazliak the book Mathematicians at War. Volterra and his French Colleagues in World War I (Springer, 2009). She has organised several international congresses and conferences and is a member of the organising committee of the Seminars of History of Mathematics of the Institut Henri Poincaré in Paris. 